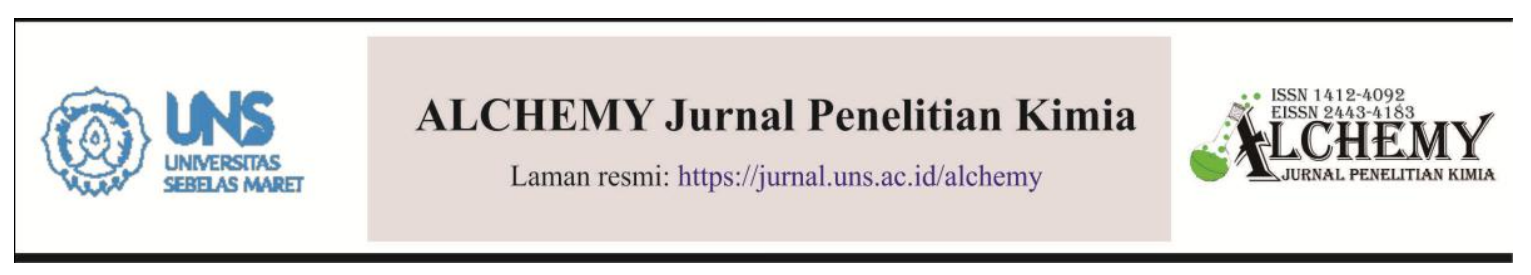

\title{
Efek Komposisi Bioadsorben $\alpha$-Keratin/Alginat Terhadap Kapasitas Adsorpsi Logam Berat Besi (Fe)
}

\author{
Elsa Ninda Karlinda Putri ${ }^{a^{*}}$, Syahna Febrianastuti ${ }^{a}$, Easy Vicky Maylinda ${ }^{a}$, Ganjar \\ Fadillah $^{b}$, Candra Purnawan ${ }^{a}$
}

${ }^{a}$ Kimia Analitik, Program Studi Kimia, FMIPA, Universtas Sebelas Maret, Jl. Ir. Sutami 36 A, Kentingan Surakarta 57126 telp. (0271) 663375

${ }^{b}$ Kimia Analitik, FMIPA, Universitas Islam Indonesia, Jl. Kaliurang 14,5, Sleman Yogyakarta 55584

* Corresponding author

E-mail: elsaninda22@student.uns.ac.id

DOI: 10.20961/alchemy.14.2.11410.323-333

Received 03 June 2017, Accepted 06 August 2018, Published Online 03 September 2018

\begin{abstract}
ABSTRAK
Penelitian terkait pengaruh komposisi $\alpha$-keratin/alginat terhadap kapasitas adsorpsi logam berat besi (Fe) telah dilakukan. Penelitian ini bertujuan untuk mengetahui karakter dan optimasi adsorpsi dari bioadsroben komposit $\alpha$-keratin/alginat terhadap daya serap logam berat Fe dalam larutan air. Proses preparasi bioadsorben $\alpha$-keratin/alginat dilakukan dengan metode enkapsulasi pada larutan $\mathrm{CaCl}_{2} 2 \%$ (b/v). Karakterisasi bioadsorben dilakukan menggunakan Fourier Transform Infra-Red (FTIR), Scanning Electron Microscopy (SEM) dan proses adsorbsi dilakukan dengan metode batch. Hasil karakterisasi IR pada komposit $\alpha-$ keratin/alginat menunjukkan terdapatnya serapan pada bilangan gelombang $1140-820,75 \mathrm{~cm}^{-1}$ yang merupakan reduksi gugus mannuronate dari alginat. Hal ini menunjukan bahwa alginat telah terikat secara kimia dengan $\alpha$-keratin. Adsorpsi logam Fe (3 ppm) dalam larutan dilakukan dengan variasi komposisi $\alpha$-keratin:alginat secara berturut-turut sebagai berikut $1: 1 ; 1: 2 ; 1: 3 ; 2: 1$ dan 3:1 (b/b). Hasil pengukuran menggunakan Atomic Absorption Spectroscopy (AAS) dengan metode kurva kalibrasi standar menunjukkan komposisi optimum penyerapan logam Fe (3 ppm) adalah 1:2 dengan kapasitas adsorpsi sebesar 205,64 mg/g. Hasil karakterisasi SEM pada komposit $\alpha$-keratin:alginat komposisi 1:2 (b/b) yang memberikan kemampuan adsorpsi yang terbesar menunjukkan bahwa permukaan rambut manusia tidak tertutup secara menyeluruh sehingga gugus aktif dan celah-celah kecil pada komposit dapat berperan dalam proses adsorpsi logam berat besi (Fe).
\end{abstract}

Kata Kunci: adsorpsi, komposit $\alpha$-keratin/alginat, logam berat Fe

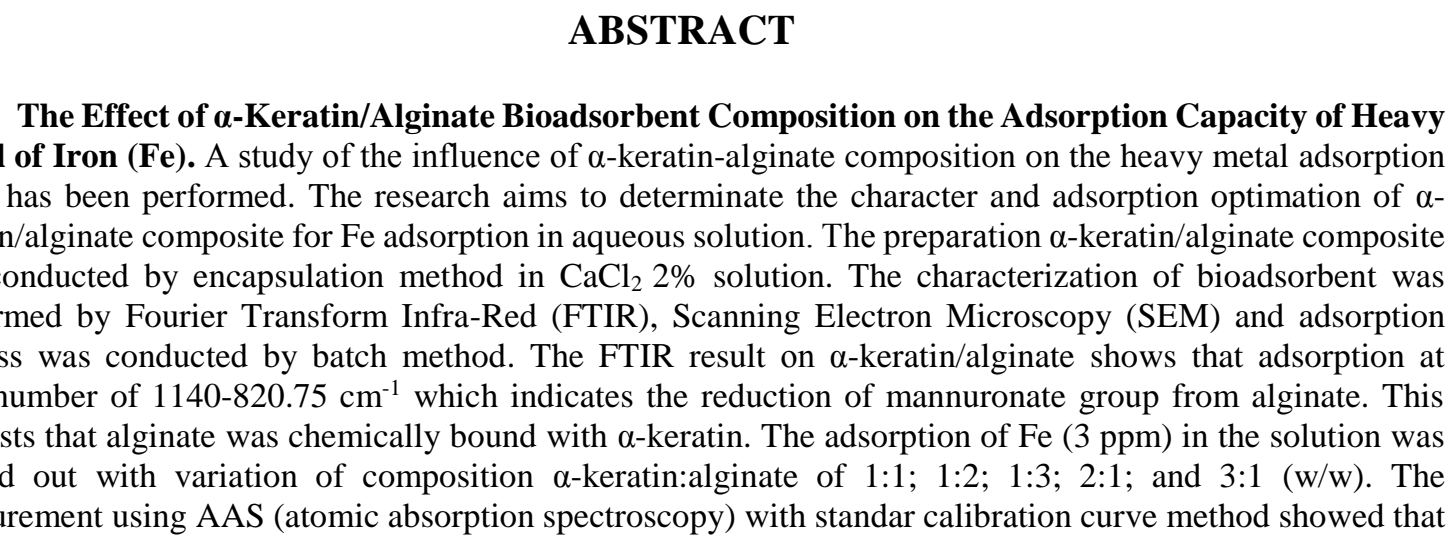
measurement using AAS (atomic absorption spectroscopy) with standar calibration curve method showed that 
optimum composition of $\mathrm{Fe}(3 \mathrm{ppm})$ adsorption was 1:2 (w/w) with adsorption capacity of $205.64 \mathrm{mg} / \mathrm{g}$. The SEM result on $\alpha$-keratin/alginate 1:2 (w/w) which had the greatest adsorption capability shows that the surface of human hair was not completely closed thus the active groups and pores can play a role in the process of adsorption of heavy metal iron $(\mathrm{Fe})$.

Keyword: adsorption, eco-friendly biomaterials, Fe heavy metal, $\alpha$-keratin/alginate

\section{PENDAHULUAN}

Pertumbuhan industri merupakan salah satu faktor agar dapat bersaing di era global saat ini. Menurut Kementerian Perindustrian, pertumbuhan industri pada tahun 2016 mencapai 5,7\%, lebih tinggi dibanding pertumbuhan ekonomi periode di tahun 2014 dan 2015 (Kementrian Perindustrian, 2016). Pertumbuhan industri tersebut menyebabkan munculnya masalah yang terkait dengan pencemaran lingkungan. Salah satu jenis cemaran hasil dari proses indsutri adalah cemaran logam berat Fe seperti pada air sumur dekat pembuangan limbah industri tekstil. Kadar logam berat seperti Fe yang tinggi dalam limbah air dapat menyebabkan efek buruk bagi lingkungan dan kehidupan manusia seperti menimbulkan bau, warna, dan koloid pada air minum yang dapat menyebabkan rasa mual dan sakit perut (Putra et al., 2014). Menurut Kementrian Kesehatan Republik Indonesia No.492/MENKES/PER/IV/2010 TANGGAL 19 April 2010 tentang persyaratan kualitas air minum, kadar Fe dalam air minum yang diperbolehkan hanya 0,3 mg/L (Kemenkes RI, 2010).

Penelitian terkait metode penghilangan kandungan Fe dalam air sudah banyak dilakukan salah satunya menggunakan teknik adsorpsi (Mandasari and Purnomo, 2016). Beberapa adsorben yang telah berhasil dikembangkan sebagai adsorben Fe antara lain karbon aktif (Bahtiar et al., 2015), zeolit alam (Munandar, 2014), kitosan-bentonit (Permanasari et al., 2010) dan nanopartikel $\mathrm{CoFe}_{2} \mathrm{O}_{4}$ (Nurdila et al., 2015).

Adsorben-adsorben berbasis senyawa anorganik dapat memberikan kinerja yang bagus, tetapi adsorben berbasis senyawa anorganik ini juga memiliki kelemahan yaitu pada proses sintesis sulit dilakukan serta memerlukan biaya yang cukup besar. Sementara adsorben bahan alam memiliki kinerja yang bagus serta memerlukan biaya yang lebih terjangkau dari pada adsorben berbasis senyawa anorganik (Firdaus, 2012).

Perkembangan riset tentang adsorben saat ini sedang banyak menggunakan material berbasis bahan organik dengan prinsip dari limbah untuk limbah seperti $\alpha$-keratin. Sumber $\alpha$-keratin banyak sekali seperti dalam bulu ayam dan rambut manusia. Kandungan kimia utama rambut adalah 88-96\% protein $\alpha$-keratin (Mitsui,1992). Hal ini menunjukkan bahwa $\alpha$-keratin memiliki potensi untuk dikembangkan lebih lanjut. Surya (2015) telah melakukan 
eksperimen mengenai pemanfaatan limbah rambut manusia sebagai adsorben pencemaran minyak di lautan. Protein $\alpha$-keratin mampu bertindak sebagai adsorben karena memiliki ikatan disulfida (R-SH), gugus fungsi hidroksil (R-OH), karbonil (R-CO-R) dan amino (R$\mathrm{NH}_{2}$ ). Oleh karena itu, rambut manusia memiliki pasangan elektron kuat seperti nitrogen, oksigen dan sulfida yang memungkinkan terjadinya proses adsorpsi kimia karena pasangan elektron tersebut dapat berkoordinasi dengan ion logam berat Fe yang bermuatan positif dan permukaannya memiliki celah-celah kecil yang mengakibatkan terjadinya adsorpsi secara fisika pada permukaan rambut (Roh et al., 2014). Ikatan disulfida terbentuk dari dua molekul asam amino sistein (Mahdavian, 2014), yang menyebabkan rambut manusia memiliki sifat mekanik yang kuat, daya tahan termal dan ketahanan terhadap degradasi fisikokimia dari lingkungan yang baik (Lin et al., 1992), namun peningkatan ketahanan fisik rambut manusia diperlukan agar dapat tahan terhadap benturan dan kerusakan lingkungan saat diaplikasikan secara langsung di lingkungan. Selain itu, kapasitas adsorpsi rambut manusia terhadap logam berat masih rendah. Oleh karena itu, perlu adanya modifikasi untuk peningkatan ketahanan fisik dan kapasitas adsorpsi rambut seperti perlindungan biomaterial rambut manusia membentuk suatu komposit.

Bahan yang dapat dijadikan sebagai pelindung biomaterial rambut manusia adalah alginat (Hartrianti et al., 2016). Alginat memiliki banyak gugus hidroksil (R-OH) dan karboksil (R-CO-R) yang dapat meningkatkan kapasitas adsorpsi logam berat Fe (Zhao et $a l .2$ 2017). Komposit bioadsorben rambut-alginat dibentuk dengan metode enkapsulasi menggunakan larutan $\mathrm{CaCl}_{2} 2 \%$ yang mengandung konsentrasi kationik tinggi. Menurut Frianda (2012), salah satu faktor yang mempengaruh kemampuan suatu material komposit dalam proses adsorpsi adalah komposisi antara $\alpha$-keratin dan alginat. Oleh karena itu, dalam penelitian ini dikaji tentang pengaruh komposisi $\alpha$-keratin dengan alginat untuk adsorpsi logam berat Fe.

\section{METODE PENELITIAN}

Bahan yang digunakan dalam penelitian ini antara lain serbuk rambut manusia, Naalginat teknis, $\mathrm{NaOH} 1 \mathrm{M}$ (Merck), $\mathrm{HCl} 37,5 \%$ p.a (Merck), $\mathrm{HNO}_{3} 65 \%$ p.a (Merck), $\mathrm{CaCl}_{2}$ (Merck), Larutan standar Fe 1000 ppm $\left(\mathrm{Fe}_{2}\left(\mathrm{SO}_{4}\right)_{3}\right)$, air deterjen ionik (merk Rinso), aseton p.a (Merck) dan aquades. Alat-alat yang digunakan antara lain penggilingan tepung, ayakan 180 mesh, pH meter, shaker Ogawa Seiki OSK 6445, neraca analitik listri Mettler PB 3000 ER-182 A, oven Memmert dan seperangkat alat gelas.

\section{Preparasi $\alpha$-keratin rambut}


Rambut yang diperoleh dari beberapa barbershop di Wonogiri dan Surakarta, dicuci dengan air deterjen ionik (merk Rinso) beberapa kali dan dijemur hingga kering. Kemudian, rambut digiling hingga halus pada ukuran 200 mesh. Serbuk rambut yang diperoleh dicuci dengan aseton p.a (Merck) selama 30 menit dan disaring dengan kertas saring whatman. Kemudian residu dikeringkan dengan oven pada suhu $40{ }^{\circ} \mathrm{C}$ selama 30 menit.

\section{Pembuatan komposit $\alpha$-keratin/alginat}

Serbuk rambut dan Na-alginat dengan perbandingan Rambut/Na-Alginat (R/A) 1/1, 1/2, 1/3, 2/1 dan 3/1 (b/b) dimasukkan pada gelas beker. Kemudian ditambahkan aquades 25 $\mathrm{mL}$ dan diaduk hingga Na-alginat larut. Larutan campuran serbuk rambut dan Na-alginat kemudian dienkapsulasi dengan larutan $\mathrm{CaCl}_{2} 2 \%$ yang direndam dalam es batu. Hasil enkapsulasi berupa komposit $\alpha$-keratin/alginat disaring dan dikeringkan menggunakan oven pada suhu $60{ }^{\circ} \mathrm{C}$ selama 8 jam (Sillerová et al., 2015). Komposit $\alpha$-keratin/alginat dikarakterisasi menggunakan FTIR untuk mengetahui ikatan dari komposit material dan SEM untuk mengetahui morfologi permukaan komposit $\alpha$-keratin/alginat

\section{Proses adsorpsi ion logam berat $\mathrm{Fe}^{3+}$ dengan komposit $\alpha$-keratin/alginat}

Larutan ion logam berat $\mathrm{Fe}^{3+}\left(\mathrm{Fe}_{2}\left(\mathrm{SO}_{4}\right)_{3}\right) 3$ ppm disiapkan dengan cara mengencerkan larutan Fe standar 1000 ppm dalam 100 mL. Kemudian larutan ion $\mathrm{Fe}^{3+} 3$ ppm ditambahkan 0,1 gram komposit $\alpha$-keratin/alginat dan diaduk menggunakan shaker selama 1 jam. Kemudian larutan tersebut disaring. Filtrat yang diperoleh diukur kadar ion logam berat $\mathrm{Fe}^{3+}$ sisa yang tidak teradsorpsi dengan menggunakan AAS dan ditentukan kapasitas adsorpsi maksimal ion logam berat $\mathrm{Fe}^{3+}$ menggunakan Persamaan 1 sebagai berikut:

$$
\text { Kapasitas Adsorb }(q e)=\frac{\left(C_{a w a l}-C_{a k h i r}\right) \times V_{\text {larutan }}}{\text { massa adsorben }}
$$

\section{HASIL DAN PEMBAHASAN}

\section{Enkapsulasi keratin dengan alginat dan karakterisasi}

Metode enkapsulasi ini dilakukan dengan menggunakan larutan $\mathrm{CaCl}_{2} 2 \%$ yang berfungsi sebagai larutan kationik untuk membentuk komposit $\alpha$-keratin/alginat (Zheng et al., 2017). Proses enkapsulasi akan menyebabkan adanya pertukaran ion antara ion $\mathrm{Ca}^{2+}$ dari larutan $\mathrm{CaCl}_{2} 2 \%$ dengan ion $\mathrm{Na}^{+}$dari Na-Alginat yang akan membentuk crosslinking pada blok G-G dan M-G dari alginat (Paredes Juárez et al., 2014). Interaksi antara $\mathrm{Ca}^{2+}$ dengan alginat akan membentuk struktur 3D yang disebut dengan model "egg-box”. Rambut akan terlindungi dalam model "egg-box" membentuk komposit bioadsorben rambut-alginat yang 
dapat digunakan sebagai bioadsorben logam berat Fe dengan adanya peningkatan ketahanan fisik dan kapasitas adsorpsi (Zhao et al., 2017). Ilustrasi reaksi pembentukan egg box dapat dilihat pada Gambar 1 dan komposit $\alpha$-keratin/alginat dapat dilihat pada Gambar 2.

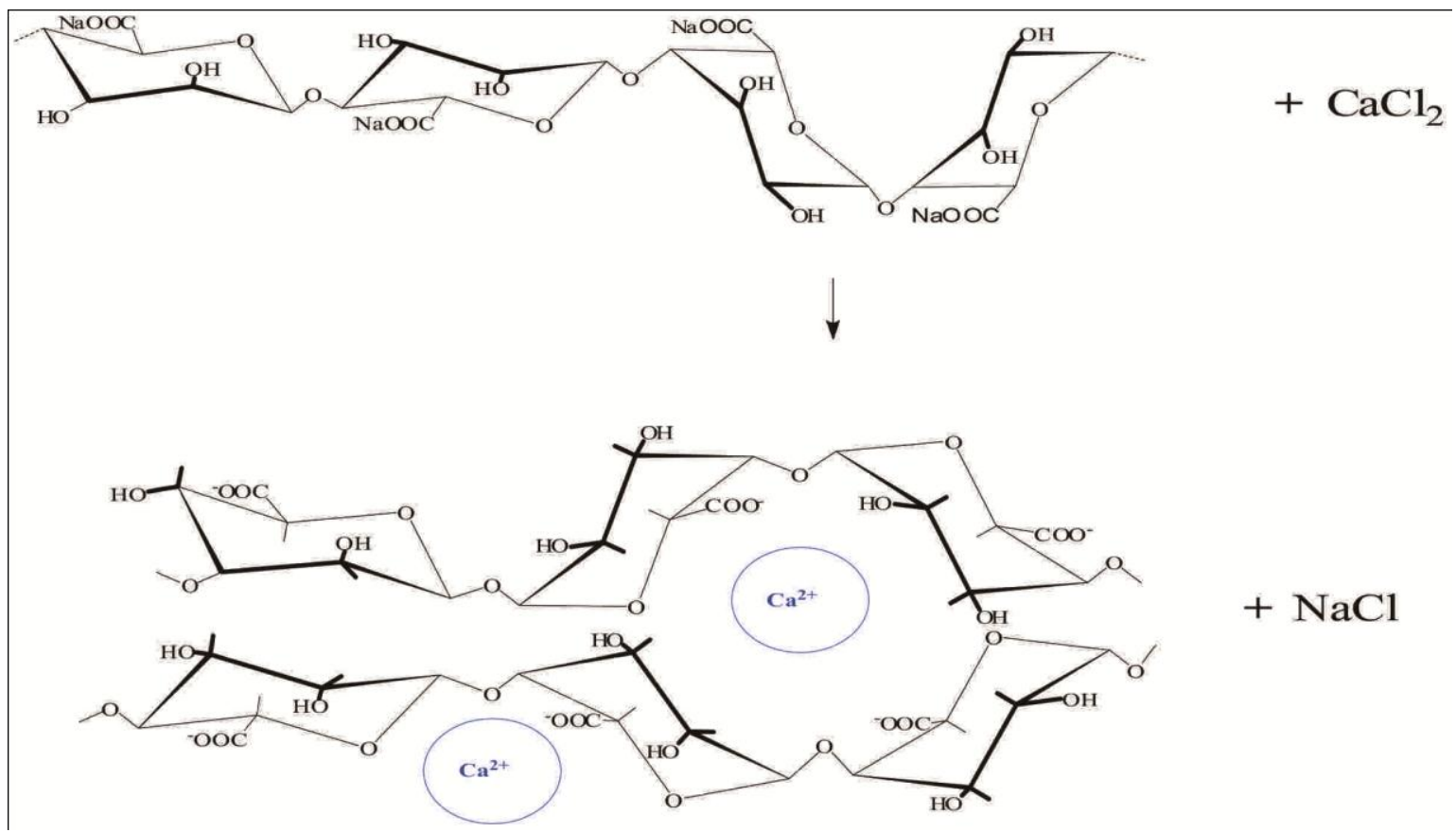

Gambar 1. Reaksi pembentukan egg box (Paredes Juárez et al., 2016).

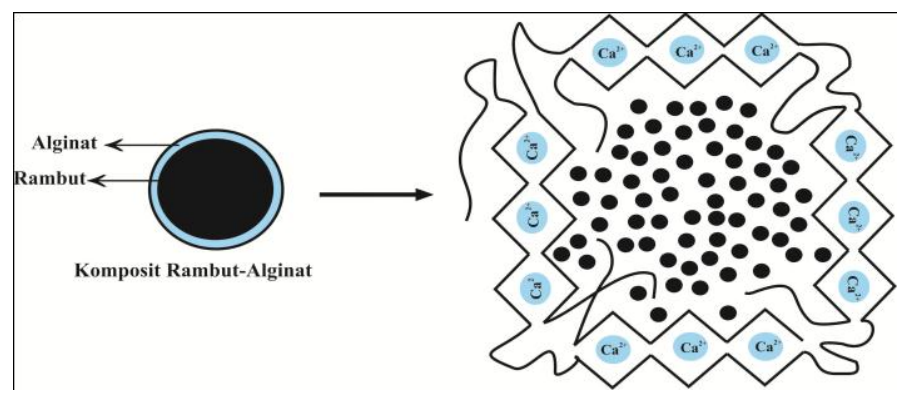

Gambar 2. Komposit $\alpha$-keratin/alginat.

Komposit $\alpha$-keratin/alginat tersebut kemudian dikarakterisasi menggunakan FTIR. Karakterisasi rambut, alginat dan komposit $\alpha$-keratin/alginat dapat diketahui dari vibrasi yang dihasikan oleh gugus fungsional pada serapan IR seperti ditunjukkan pada Gambar 3. 


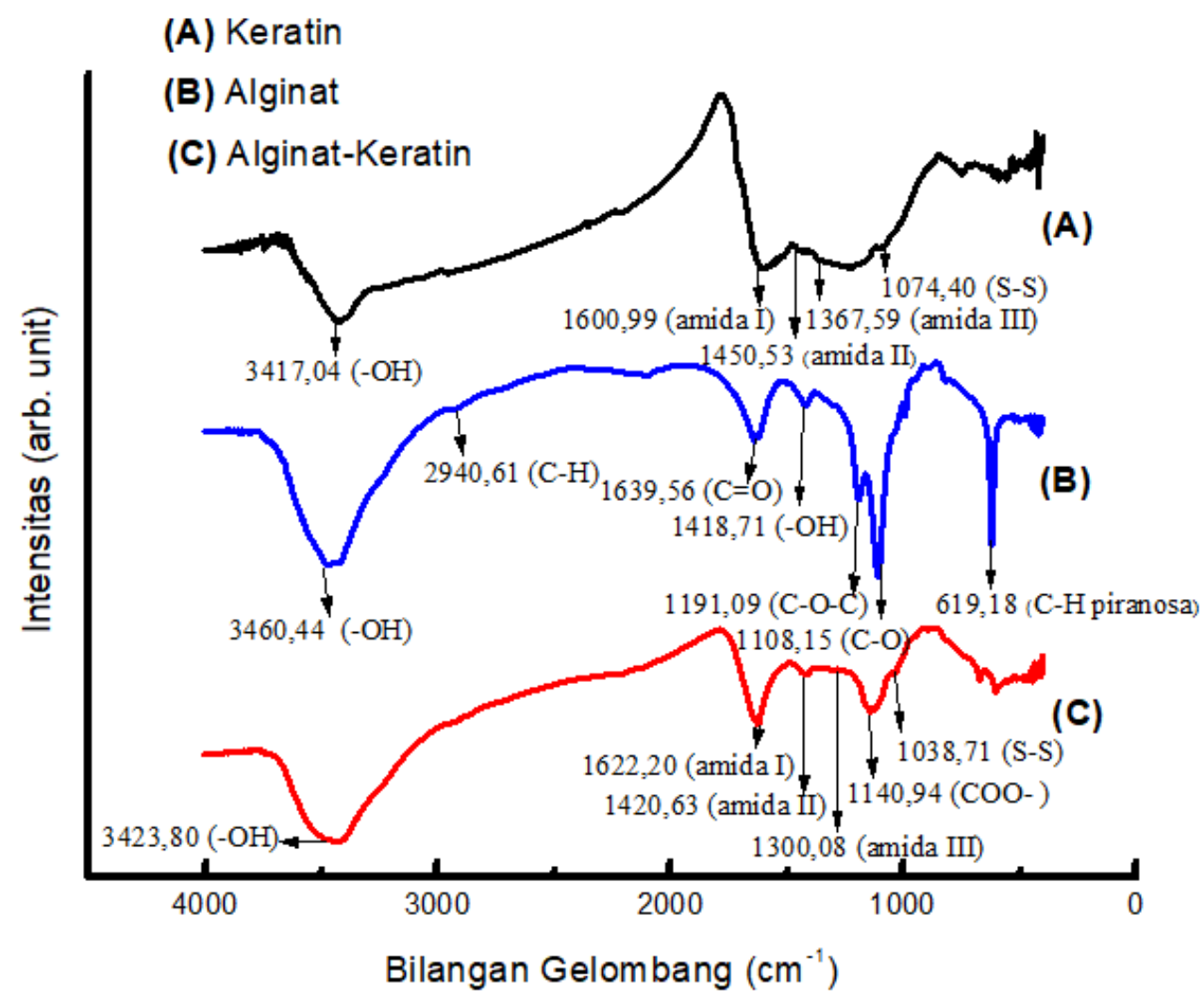

Gambar 3. Spektra FTIR (A) Keratin, (B) Alginat, dan (C) bioadsorben $\alpha$-keratin/alginat.

Spektra FTIR pada keratin dan $\alpha$-keratin/alginat menunjukkan terdapat serapan vibrasi ikatan $\mathrm{OH}$ stretching pada bilangan gelombang 3471,04 dan $3423,80 \mathrm{~cm}^{-1}$. Selain itu, terdapat serapan karakteristik ikatan peptida (-CONH-) dengan tiga daerah serapan yaitu Amida I, Amida II, dan Amida III. Daerah serapan amida I menunjukkan adanya serapan vibrasi $\mathrm{C}=\mathrm{O}$ stretching pada bilangan gelombang 1600,99 dan $1622,20 \mathrm{~cm}^{-1}(\mathrm{Kim}$, et al., 2013). Daerah amida II menunjukan adanya serapan vibrasi C-N stretching dan N-H bending pada bilangan gelombang 1450,53 dan 1420,63 $\mathrm{cm}^{-1}$ (Cardamone, 2010). Daerah amida III menunjukkan adanya serapan vibrasi $\mathrm{N}-\mathrm{H}$ bending, $\mathrm{C}-\mathrm{N}$ stretching pada ikatan $\mathrm{O}=\mathrm{C}-\mathrm{N}$ dengan bilangan gelombang 1367,59 dan 1300,08 $\mathrm{cm}^{-1}$ (Baddiel, 1968). Pada keratin dan komposit $\alpha$-keratin/alginat juga terdapat serapan gugus disulfida (S-S) di daerah bilangan gelombang 1074,40 dan 1038,10 $\mathrm{cm}^{-1}$.

Puncak serapan inframerah yang paling karakteristik dalam asam alginat ditunjukkan dengan adanya serapan gugus C-O-C glikosida di daerah bilangan gelombang $1191,09 \mathrm{~cm}^{-1}$ dan serapan gugus alkil (C-H) khas piranosa pada bilangan gelombang 991,45- 619,18 $\mathrm{cm}^{-1}$ (Arifudin, 2002). Pada analisis FTIR ini, juga menunjukkan serapan gugus C-O alkohol pada bilangan gelombang $1108,15 \mathrm{~cm}^{-1}$, serapan gugus $\mathrm{C}-\mathrm{H}$ alkana streching pada bilangan gelombang 2940,61 $\mathrm{cm}^{-1}$; dan serapan gugus karbonil $(\mathrm{C}=\mathrm{O})$ pada bilangan gelombang 
1639,56 $\mathrm{cm}^{-1}$ (Kosman, 2011). Komposit bioadsorben rambut-alginat juga menunjukkan terdapatnya serapan pada bilangan gelombang $1600 \mathrm{~cm}^{-1}$ yaitu serapan gugus mannuronat dan gugus guluronat $\left(\mathrm{COO}^{-}\right)$dari alginat yang memiliki intensitas puncak lebih rendah. Hal ini menunjukkan bahwa proses pembentukan ikatan silang antara ion $\mathrm{Ca}^{2+}$ dari $\mathrm{CaCl}_{2}$ dengan $\mathrm{Na}^{+}$-alginat pembentukan komposit bioadsorben rambut-alginat telah berhasil (Hartrianti et al., 2016).

\section{Penentuan adsorpsi ion logam berat $\mathrm{Fe}^{3+}$ dengan komposit $\alpha$-keratin/alginat pada variasi komposisi berat rambut dan alginat}

Capaian kedua adalah pengujian bioadsorben untuk penyerapan ion logam berat $\mathrm{Fe}^{3+}$ di dalam larutan air. Secara fisik, jumlah komposisi alginat mempengaruhi kekerasan dari kapsul kasil proses enkapsulasi. Hal ini disebabkan, karena semakin banyak ion $\mathrm{Na}^{+}$yang bertukar dengan ion $\mathrm{Ca}^{2+}$ maka kekerasan semakin meningkat (Sillerová et al., 2015). Namun, jika semakin banyak alginat terkandung dalam komposit belum pasti akan menghasilkan proses adsorbsi yang optimal. Hal ini dipengaruhi oleh adanya faktor kerapatan dari komposit yang dihasilkan. Oleh karena itu, diperlukan pengujian variasi komposisi antara $\alpha$-keratin dengan alginat untuk mengetahui komposisi komposit $\alpha$ keratin/alginat yang paling optimum untuk adsorpsi. Hasil analisis adsorpsi ion logam berat $\mathrm{Fe}^{3+}$ dengan variasi komposisi komposit $\alpha$-keratin/alginat disajikan pada Gambar 5.

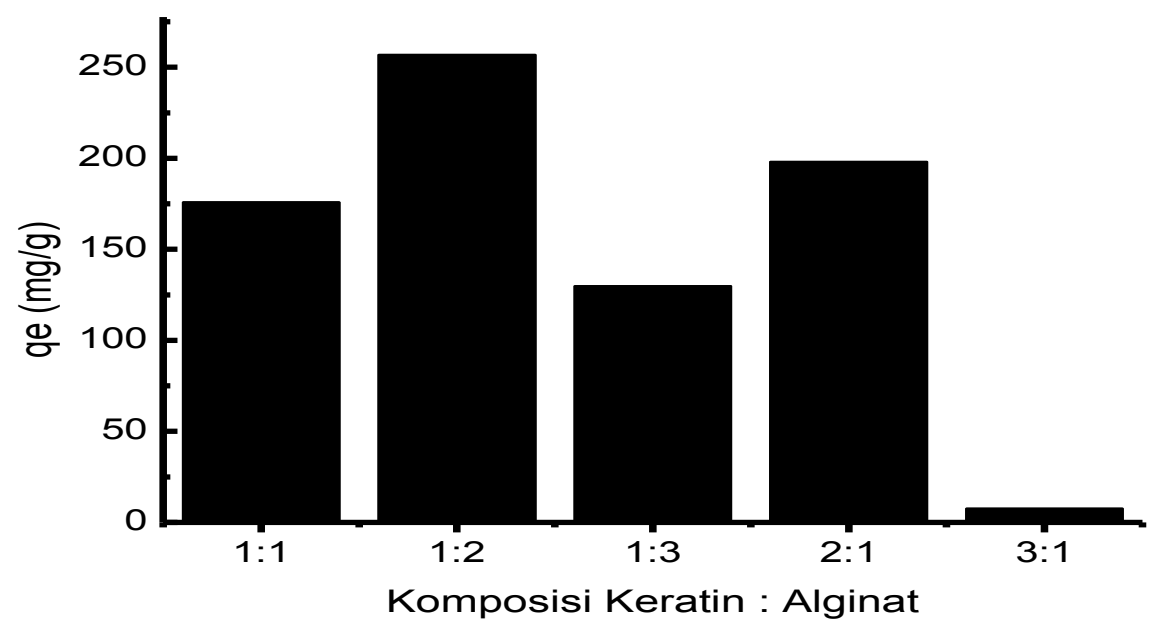

Gambar 4. Pengaruh Komposisi Komposit $\alpha$-keratin/alginat Terhadap Kapasitas Adsorpsi Ion Logam Berat $\mathrm{Fe}^{3+}$.

Komposisi antara rambut dan alginat mempengaruhi kapasitas adsorpsi terhadap ion logam berat $\mathrm{Fe}^{3+}$, dimana diduga semakin besar komposisi alginat yang diberikan maka kerapatan dari komposit $\alpha$-keratin/alginat semakin berkurang. Semakin kecil kerapatan 
mengakibatkan tertutupnya permukaan rambut oleh alginat semakin besar sehingga kapasitas adsorpsi komposit $\alpha$-keratin/alginat semakin rendah. Namun apabila komposisi alginat yang diberikan sedikit maka kapasitas adsorpsi yang dimiliki oleh komposit $\alpha$ keratin/alginat berkurang. Gambar 4 menunjukkan bahwa komposisi antara $\alpha$-keratin dari rambut dengan alginat sebesar 1:2 (b:b) memiliki kapasitas adsorpsi terhadap logam berat $\mathrm{Fe}^{3+}$ terbesar yaitu $257,05 \mathrm{mg} / \mathrm{g}$. Hal ini menunjukkan pembentukan komposit $\alpha-$ keratin/alginat mempengaruhi kerapatan dari adsorben yang dapat dilihat pada karakterisasi menggunakan SEM (Gambar 5).

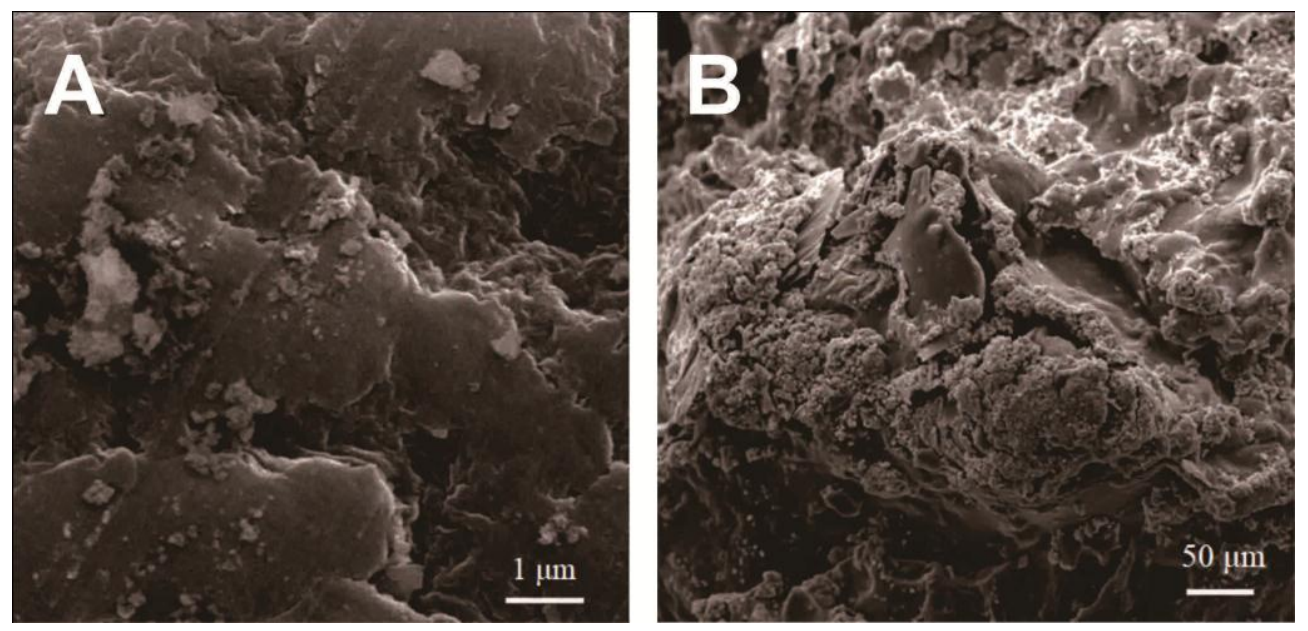

Gambar 5. Hasil Analisis SEM (A) alginat dan (B) komposit $\alpha$-keratin/alginat.

Gambar 5(a) dan 5(b) menunjukkan berturut-turut morfologi dari alginat dan komposit $\alpha$-keratin/alginat. Hasil karakterisasi SEM ini menunjukkan bahwa penggabungan $\alpha$-keratin dan alginat menghasilkan perubahan morfologi adsorben. Permukaan komposit $\alpha$ keratin/alginat komposisi 1:2 (b/b) sebagaimana yang terlihat pada Gambar 5(B), memperlihatkan morfologi yang lebih kasar. Hal ini diyakini berpengaruh pada adsorpsi $\mathrm{Fe}^{3+}$ pada permukaan komposit adsorben karena diduga gugus aktif dalam komposit $\alpha$ keratin/alginat 1:2 (b/b) yaitu $-\mathrm{OH}, \mathrm{COO}-,-\mathrm{NH}, \mathrm{C}=\mathrm{O},-\mathrm{CN}$ dan $\mathrm{S}-\mathrm{S}$ lebih banyak daripada komposisi yang lain sehingga interaksi antara gugus fungsi aktif dengan ion logam $\mathrm{Fe}^{3+}$ pada permukaan komposit $\alpha$-keratin/alginat menjadi lebih besar dan kapasitas adsorpsi meningkat.

\section{KESIMPULAN}

Komposisi antara $\alpha$-keratin dari rambut dengan alginat mempengaruhi kerapatan dari komposit $\alpha$-keratin/alginat. Semakin besar komposisi alginat yang diberikan maka permukaan rambut manusia yang memiliki gugus fungsi dan celah-celah kecil akan tertutupi 
oleh alginate, sedangkan semakin kecil komposisi alginat yang diberikan maka gugus fungsi yang berperan dalam proses adsorpsi sedikit. Komposisi antara $\alpha$-keratin dari rambut dengan alginat sebesar 1:2 (b/b) dengan kapasitas adsorpsi sebesar 257,05 mg/g.

\section{UCAPAN TERIMA KASIH}

Penulis mengucapkan terimakasih kepada DIKTI (Direktorat Jenderal Pendidikan Tinggi) atas bantuan dana melalui hibah PKM (Program Kreativitas Mahasiswa) 2017 serta fasilitas laboratorium dan instrument analisis dalam proses penyelesaian riset ini.

\section{DAFTAR PUSTAKA}

Arifudin., 2002. Pembuatan Natrium Alginat Dari Alga Coklat (Sargassum Filipendula $C$. Agarth) Dengan Menggunakan Pelarut Organik. Skripsi. Universitas Lampung, Lampung.

Baddiel, D.B., 1968. Structure and Reaction of Human Hair Keratin: an Analysis by Infrared Spectroscopy, Journal of Molecular Biology 38, 181-199. doi: 10.1016/00222836(68)90405-1.

Bahtiar, A., Faryuni, I.D., and Jumarang, M.I., 2015. Adsorbsi Logam Fe Menggunakan Adsorben Karbon Kulit Durian Teraktivasi Larutan Kalium Hidroksida, PRISMA FISIKA 3(1), 5-8.

Cardamone, J.M., 2010. Investigating The Microstructure of Keratin Extracted From Woll: Peptide Sequence (MALDI-TOF/TOF) and Protein Conformation (FTIR), Journal of Molecular Structure 969(3), 97-105. doi: 10.1016/j.molstruc.2010.01.048.

Firdaus, M.L., 2012. Studi Perbandingan Berbagai Adsorben Sintesis dan Alami untuk Mengikat Logam Berat, Artikel Ilmiah. Universitas Bengkulu, Bengkulu.

Frianda, R.A., 2012. Sintesis Komposit Kitosan/Polimetil Metakrilat/Montmorillonite Sebagai Adsorben Zat Warna, Skripsi. Universitas Indonesia, Depok.

Hartrianti, P., Nguyen, L.T.H., Johanes, J., Chou, S.M., Zhu,P., Tan, N.S., Tang, M.B.Y., and $\mathrm{Ng}$, K.W. 2016. Fabrication and Characterization of a Novel Crosslinked Human Keratin- Alginate Sponge, Journal of Tissue Engineering and Regenerative Medicine 11(9), 2590-2602. doi: 10.1002/term.2159.

Kemenkes RI No. 492/Menkes/PER/IV/2010.

Kementrian Perindustrian. 2016. Target Pertumbuhan Industri 5,7\%. $<$ http://kemenperin.go.id/artikel/13740/Tahun-2016,-Target-Pertumbuhan-Industri5,7-Persen $>$ (diakses pada 10 November 2016).

Kim, K.S., Shin, M.K and Park, H.K., 2013. Effect of Scalp Dermatitis on Chemical Property of Hair Keratin, Spectrochimica Acta Part A: Molecular and Biomolecular Spectroscopy 109, 226-231. doi: 10.1016/j.saa.2013.02.009.

Kosman, R. 2011. Pemurnian Natrium Alginat Dari Sargassum Duplicatum J.G. Agardh, Turbinaria Decurrens (Bory) Dan Turbinaria Ornata (Turner) J. Argardh Asal Perairan Ternate, Maluku Utara, Majalah Farmasi dan Farmakologi 5(1), 30-34. 
Lin, X., Lee, C.G., Casale, E.S., and Shih, J.C.H., 1992. Purification And Characterization of a Keratinase from a Feather-Degrading Bacillus Iichenoformis Strain, Applied and Enviromental Microbiology 58(10), 3271-3275.

Mahdavian, L., 2014. Simulation of Heavy Metal Removal by $\alpha$-Keratin Nano-Structure of Human Hair From Enviroment, Journal of Enviromental Treatment Techniques 2(2), 31-35.

Mandasari, I., and Purnomo, A. 2016. Penurunan Ion Besi (Fe) dan Mangan (Mn) dalam Air dengan Serbuk Gergaji Kayu Kamper, Jurnal Teknik ITS 5(1), 1-5. doi: 10.12962/j23373539.v5i1.15113.

Mitsui, T., 1992. New Cosmetic Science. Amsterdam: Elsevier Science B. V .

Munandar, A., 2014. Adsorpsi Logam Pb dan Fe Dengan Zeolit Alam Teraktivasi Asam Sulfat, Skripsi. Universitas Islam Negeri Sunan Kalijaga, Yogyakarta.

Nurdila, F.A., Asri, N.S., and Suharyadi, E., 2015. Adsorpsi Logam Tembaga (Cu), Besi (Fe), dan Nikel (Ni) dalam Limbah Cair Buatan Menggunakan Nanopartikel Cobalt Ferrite $\left(\mathrm{CoFe}_{2} \mathrm{O}_{4}\right)$, Jurnal Fisika Indonesia 19(55), 23-27.

Paredes Juárez, G.A., Spasojevic, M., Faas, M.M., and de Vos, P., 2014. Immonulogical and Technical Consideration in Application of Alginate-Based Microencapsulation System, Bioengeneering and Biotechnology 2(26), 1-15. doi: 10.3389/fbioe.2014.00026.

Permanasari, A,. Siswaningsih, W., and Wulandari, I., 2010. Uji Kinerja Adsorben KitosanBentonit Terhadap Logam Berat dan Diazinon Secara Simultan, Jurnal Sains dan Teknologi Kimia 1(2), 121-134.

Putra, D.E., Astuti, F.P and Suharyadi, E., 2014. Studi Penurunan Kadar Logam Besi (Fe) Pada Limbah Batik dengan Sistem Purifikasi Menggunakan Adsorben Nanopertikel Magnetic $\left(\mathrm{Fe}_{3} \mathrm{O}_{4}\right)$, Prosiding Pertemuan Ilmiah XXVIII HFIISSN : 0853-0823.

Roh, H.G., Kim, S.G., and Jung, J., 2014. Adsorption of Heavy Metal Ions $\left(\mathrm{Pb}^{2+}, \mathrm{Cu}^{2+}\right)$ on Perm-Lotion-Treated Human Hair, Korean Journal of Chemical Engineering 31(2), 310-314. doi: 10.1007/s11814-013-0222-5.

Sillerová, H., Komárek, M., Liu, C., Poch, J., and Vilaescusa, I., 2015. Biosorbent Encapsulation in Calcium Alginate: Effects of Process Variables on $\mathrm{Cr}(\mathrm{IV})$ Removal From Solutions, International Journal of Biological Macromolecules 80, 260-270. doi: 10.1016/j.ijbiomac.2015.06.032.

Surya, S.A., 2015. Pemanfaatan Limbah Rambut Manusia Sebagai Pelampung Adsorben Pencemaran Minyak di Lautan, Karya Tulis Ilmiah. Universitas Sebelas Maret.

Zhao, X., Wang, H., Peng, H., Wang, L., Lu, X.H., Huang, Y.J., Chen, J., Chao, T.K., 2017. Buoyant ALG/HA/HGMs Composite Adsorbents for Highly Efficient Removal of Copper from Aqueous Solution and Contaminated Kaolin Soil, Chemical Engineering Journal 327, 244-256. 10.1016/j.cej.2017.06.085.

Zheng, X.M., Dou, J.F., Xia, M., Ding, A.Z., 2017. Ammonium-Pillared Montmorilonite$\mathrm{CoFe}_{2} \mathrm{O}_{4}$ Composite Caged in Calcium Alginate Beads for the Removel of $\mathrm{Cs}^{+}$from Wastewater, Carbohidrat Polymers 167, 306-316. doi: 10.1016/j.carbpol.2017.03.059. 